\title{
県境地域における地域連携計画の分析 \\ A STUDY ON THE REGIONAL LINKING PLANS \\ AROUND PREFECTURE BORDER AREAS
}

\author{
戸田敏行*，大貝 彰** \\ Toshiyuki TODA and Akira OHGAI
}

\begin{abstract}
This study is the analysis for the characteristics of regional linking plans which are around prefecture borders. The analysis is based on questionnaires and a case study for 9 regional plans created by organizations which are linked around the prefecture borders. The followings are the findings of the study.

1) Conceptual Plan for General field (CPG), Conceptual Plan for Specific field (CPS) and Action Plan for Regionally linked organization (APR) are demanded by the local govemments office which are in the prefecture boarder regions.

2) CPG is influenced by the national government plan. The vitalization of industry and information/communication are the main fields of CPG Each projects of CPG tend to concentrate into the prefecture border region.

3) CPS is based on the ideas from the prefecture border area. The promotion of tourism and related business is the main purpose of CPS. Each projects of CPS tend to concentrate into individual prefecture.

4) APR planed for the projects which the prefecture border linked organizations are able to carry out. Each projects of APR tend to concentrate in inner/outer-area of the prefecture border region.
\end{abstract}

Keywords: prefecture borders, regional linking, regional planning, regional authority

県境、地域連携、地域計画、地方分権

1. はじめに

\section{$1-1$ 研究の背景}

市町村合併の進展等から道州制に代表される県制度变革の検討が 全国的に活発化して拈り、北東北 3 県合併など地域レベルでの試み も芽生えている。こうした状況から、県境地域の地域連携を政策的 に促進する必要性が高まるものと考えられる。そこで筆者らは県境 地域における政策的地域連携の主体として地域連携組織に着目し、 65 地域連携組織（57 県境地域）を対象とした分析を行った ${ }^{1) 。 こ ~}$ こでは地域連携組織の活動地域を 7 地域類型、活動内容を 7 活動類 型に分類した上で、地域連携組織が活動分野、事務局体制、活動地 域特性に影響を受けながら活動を展開している状況を明らかにした。

県境地域は県境によって行政システム注1) が分断されていること に政策的な課題性があると考えられるが、既報調查は分断された行 政システムを組織的に連携するという視点から行ったものである。 次に組織的な連携を地域づくりに発展させる観点からは、県境地域 を対象とした多様な計画（以下、地域連携計画）立案が必要と考え られる。また既報調査に扔いても、地域連携組織の中に計画を立案 している事例が見受けられた。こうした状況から県境地域の地域づ くりを計画的に促進するために、県境地域における地域連携計画の
特性と課題を明確にすることが重要と考えられる。

\section{$1-2$ 本研究の目的と既往研究}

本稿は以上の様な問題意識のもとで、県境地域連携組織が策定す る地域連携計画について、次の 3 点を明らかにすることを目的とし ている。

(1)57 県境地域に所属する自治体（市町村）からみた、県境地域にお ける地域連携計画の必要性と計画内容、計画の要素と考えられる連 携事業の必要性と事業内容

(2)地城連携計画事例からみた計画の特徽、計画で提案される連携事 業の特徴

(3)計画事例の自治体評価と課題

県境地域において地域連携の方法を分析した既往論文としては、 北陸地域を対象とした嶋田らの研究がある 2)。しかし県境地域の計 画策定という視点からは、事例紹介 3 に止まっており既往研究は見 あたらない。

\section{$1-3$ 研究の方法}

以下の方法で調査分析を進めた。

(1)県境地域自治体アンケート

既報で把握した 57 県境地域に属する自治体（1391 市町村）への
* 社東三河地域研究センター 主席研究員・工修

** 豊橋技術科学大学建設工学系 教授・工博
Principal Researcher, Higashimikawa Regional Research Center, M. Eng. Prof., Dept. of Architecture and Civil Eng., Toyohashi Univ. of Tech., Dr. Eng. 
アンケート調查を郵送配布で行い、郵送回収で 649 票（回収率 46.7\%）を得た。アンケート記入者は、県境地域状況に精通してい ると考えられる広域担当者とした。全自治体に対して地域連携計画 の必要性と内容、連携事業の必要性と内容を設問として抢り、事例 計画対象自治体に対しては計画の評価に関する設問を加えた。実施 期間は平成 16 年 10 月 18 日〜 12 月 25 日である。

(2)地域連携計画事例分析

65 地域連携組織のうち地域連携計画策定を行っていると既報調 査で回答した 20 組織事務局にヒアリングし、a.現状分析、b.計画の 目標、c.事業提案の 3 項目を含んだ計画書を作成している 9 地域の 計画書を抽出した注2）（表 1)。続いて計画書の内容を把握し、提案 される連携事業の特徴を分析した。また計画立案の背景については、 連携組織事務局に現地ヒアリングを行った。

\section{2. 県境地域自治体アンケート分析}

\section{2-1連接組織活動における地域連捞計画策定の必要性}

地域連携計画の必要性について、自治体アンケートから検討する。 図 1 は、既報で把握した連携組織の 6 カテゴリー 25 活動について、 連携組織の活動として必要と回答された比率（アンケートで「不可 欠」と「望ましい」を合わせた比率。以下、必要比率。と）と、連携組 織で活動実施している比率（以下、実施比率）を比較したものであ る。必要比率と実施比率の平均值を用いて 4 象限に区分し 6 カテゴ リー別に活動分布の特徴をみる。「A：政策提言」はI・II 象限に分 布して招り、自治体必要比率は高く比較的実施もなされている。次 に「B：会議」と「C：情報発信」はI・III象限に主として分布し ており、自治体必要比率が高い活動ほど実施比率も高くなる傾向を 示している。これらは自治体必要性に対応した活動実施状況にある と思える。一方「D：啓蒙イベント」は、III・IV象限に分布してお り自治体必要比率が他の活動に比べ低い状況にある。特に「一䈏所 に集合する住民イベント」、「地域内を移動する住民イベント」は実 施比率が高いが自治体必要比率は低くなっている。「住民イベント」 はこれまで実施例が多く、新たな活動を要望している自治体が多い ものと思える。また「E：人的交流」は主として II象限に分布して おり自治体必要比率、実施比率共に比較的低い状況である。最後に $「 F ：$ 他団体との連携」は【衰限であり、自治体必要比率は高いが 実施比率が低く、今後実施の必要性がある活動と思える。「A2：地 域連携計画（県境地域を対象とした計画）策定」は「A：政策提言」 に属して招り、自治体必要比率は $75 \%$ （不可欠 $13.3 \%$ 、望ましい $61.7 \%)$ と 25 活動の中では高く、連携組織実施比率は $35.2 \%$ と全 活動平均值をやや上回る状況にあることが分かる。これらから地域 連携計画策定は、連携組織の活動として、自治体の必要性と実施可 能性が比較的あるものと考えられる。

\section{2-2 地域連拱計画の分類と傾向}

次に自治体が必要としている地域連携計画の分類を検討する。ま ず地域連携計画の内容として(1)計画実施主体、(2)計画分野、(3)計画 段階の 3 点を考える。(1)行政システムが分断され共通の事業実施主 体を持ちにくい県境地域では、地域を構成する複数の活動主体を想 定する地域計画と、連携組織が主な実施主体となる組織活動計画の 場合が想定できる。次に(2)計画分野では総合的に多分野を扱う場合 と特定の分野に限定する場合が考えられる。また(3)計画段階では、
発想・構想に相当するビジョン段階と事業実施にあたる事業整備段 階が考えられる。これらから地域連携計画の分類を図 2 の様に(1)総 合的な地域ビジョン (以下、総合ビジョン)、(2)分野を限った地域ビ ジョン (以下、分野ビジョン)、(3)総合的な事業整備計画（以下、総 合整備）、(4)分野を限った事業整備計画（以下、分野整備）、(5)連携 組織を中心とした連携活動計画 (以下、連携活動計画)を想定する。

\begin{tabular}{|c|c|}
\hline 敦画名 & 策定時期 \\
\hline 南とうほくSUNプラン & 平成 6 年 6 月 \\
\hline 21世紀FIT構想推進指針 & 5年 9月 \\
\hline 俱利伽囉越えいにしえの街道整備竍画 & 8年 2月 \\
\hline 日本の心のふるさとゾーン整備構梖 & 平成 5年 7月 \\
\hline 富士箱根伊豆交流圈構想 & 平成 11年 3月 \\
\hline 三遠南信地域交流ネットワーク推進整備計画 & 平成 9年 3月 \\
\hline 島根:山口県境地域共同アクションプログラム & 平成 12年 3月 \\
\hline 九州中央77地域活性化ピジョ & 平成 11 年 7 月 \\
\hline やまなみミリオン回廊 & 平成 13年 3月 \\
\hline
\end{tabular}

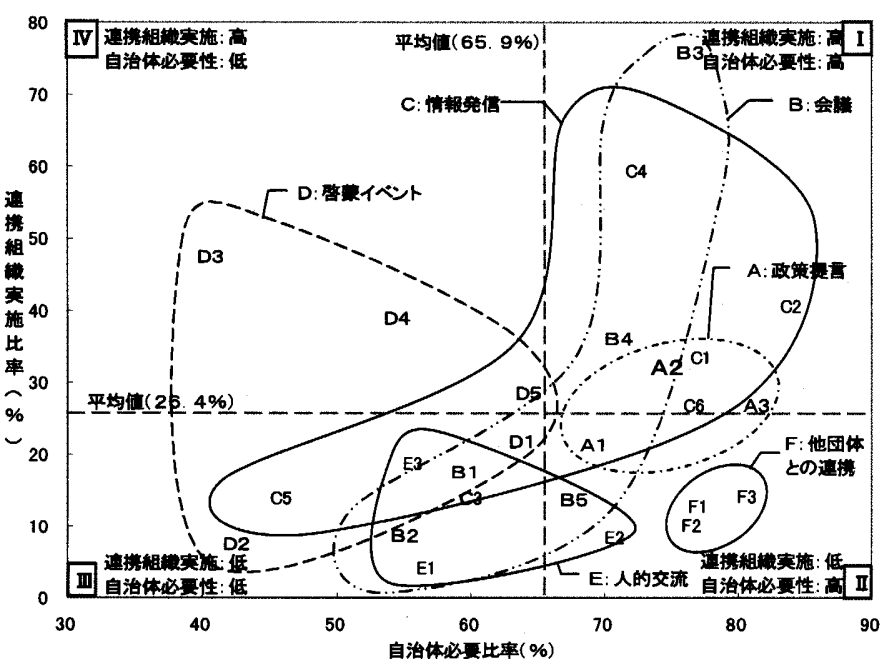

\begin{tabular}{|c|c|c|c|}
\hline (6カテゴリー) & \multicolumn{3}{|c|}{ (25活哩) } \\
\hline A: 政策提娄 & 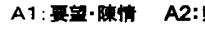 & 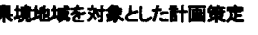 & A3: 䜕查研究 \\
\hline B: 会篮 & \multicolumn{3}{|c|}{ 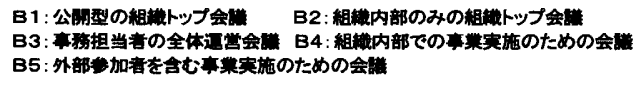 } \\
\hline C: 怕報鬼俉 & 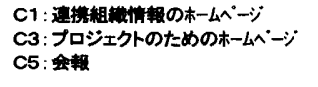 & $\begin{array}{l}\mathrm{C2}: \text { 地城什 } \\
\mathrm{C4}: \text { パンフ } \\
\mathrm{C6}: \text { : }\end{array}$ & $\begin{array}{l}\text { 转のホームページ } \\
\text { レัト } \\
\text { ティアの活用 }\end{array}$ \\
\hline D: 登震イベント & \multicolumn{3}{|c|}{ 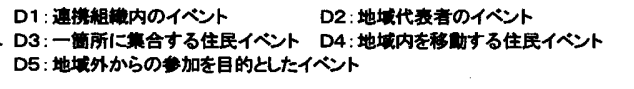 } \\
\hline$E$ : 人的交流 & E1: 人皁交流 & E2: 研修会 & : 視電 \\
\hline 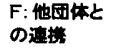 & F1: 行政団体との尰㩲 & F2: 経济団体との尰㩲 & : 市民団体との尰掽 \\
\hline
\end{tabular}

図 1 連拱組織活動における実施比率と自治体必要比率

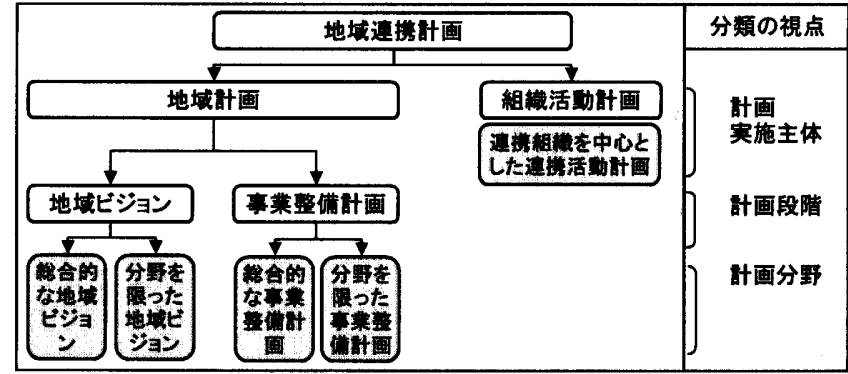

図 2 地域連拱計画の分類 
図 3 は自治体が属する県境地域の地域連携計画として、「望ま しい」計画分類を回答した比率である。まず「その他」とする回 答は $1 \%$ 以下であり、前記 5 種類の計画分類で地域連携計画に対 する自治体意向が概ね捉えられていると推測される。分類別では、 総合ビジョン $(29.8 \%)$ 、連携活動計画 $(23.1 \%)$ 、分野ビジョン (20.9\%) が高く、総合整備 $(12.6 \%)$ 、分野整備 $(8.3 \%)$ は低 い。これらから自治体は地域連携計画に対し、事業整備計画より も地域ビジョンおよび連携活動計画を求める傾向がある。

次に各計画分類の特徴を、既報で分類した地域類型注 3) 別の選 択傾向から考察する。まず総合ビジョンと分野ビジョンについて みると、空間が集中しており最も人口が集積している「都市型」 と、人口が最も少ない「中山間地型」で分野ビジョンが総合ビジ ヨンを上回っている。多様な連携を取りやすい「都市型」では特 定分野を選択することで連携の効果を図ろうとしているものと考 えられる。また「中山間地型」では限られた凟源を有効活用する ために分野ビジョンが選択される傾向がある。一方、総合ビジョ ンは産業がバランスしており、一定の人口集積と空間の広がりを 有している「広域 (商業・工業) 型 (37.3\%)」が高くなっている。 次に、総合整備と分野整備についてみる。総合整備では、人口集 積が大きく広域に及ぶ「県ブロック型 $(21.1 \%)$ 」「県中心都市連 携型 $(16.3 \%) 」 か ゙$ 平均 $(12.6 \%)$ を上回っており、広い範囲で多 くの事業を有している地域が選択している。一方、分野整備では

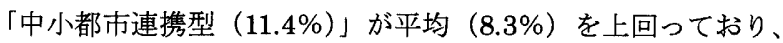
比較的限られた地域で特定の事業に集中する状況がみてとれる。 最後に連携活動計画では「広域 (工業・商業) 型 $(26.7 \%)$ 小「都 市型 $(30 \%)$ 」、「中小都市連携型 $(29.5 \%)$ 、「中山間地型 $(37.5 \%) 」 か ゙$ 平均 $(23.1 \%)$ を上回っている。特に空間の集中性 が高い地城ほど、連携活動計画が選択される傾向がある。これら の地域は自治体数が少なく、連携組織の活動が有効に機能しやす いと考えられる。

この様に地域連携計画には、県境地域の地域状況を反映した計 画内容が期待されていると言える。

\section{2-3 連携事業の特徽}

\section{1）分野別の特徴}

計画で提案されることが想定される連携事業について検討する。 図 4 は県境を越える連携事業の必要性を、8カテゴリー、28 分野 別に示したものである。県境地域連携を「不可欠」とするものは 全分野平均 $11 \%$ 、「出来れば進めたい」とするものは $36.6 \%$ であ り、これらの合計 $47.6 \%$ 連携の必要比率と判断できる。次に必 要比率に着目してカテゴリ一別の傾向をみる。まず地域基盤整備

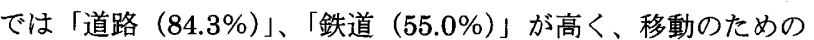

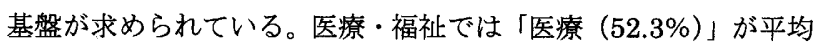
を上回って括り、医療体制での連携が求められる。次に通信・情 報は大半の分野が平均を上回り情報交流の必要性を示している。 特に「情報発信 $(73.5 \%)$ 」、情報交流拠点・体制 $(65 \%)$ 」が高

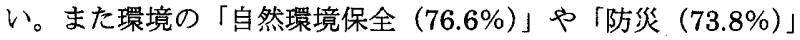
が高く、自然環境や災害に対する県境地域連携が期待されている

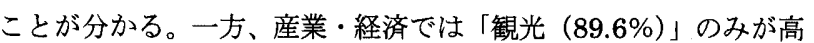
く観光における連携の重要性がみてとれる。最後に教育・文化で

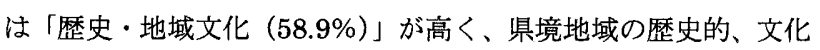

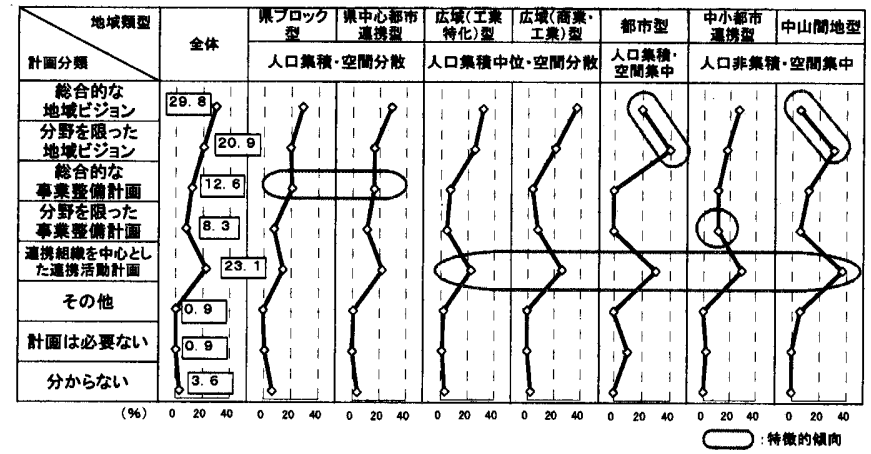

図 3 地域連携計画分類別一の期待度

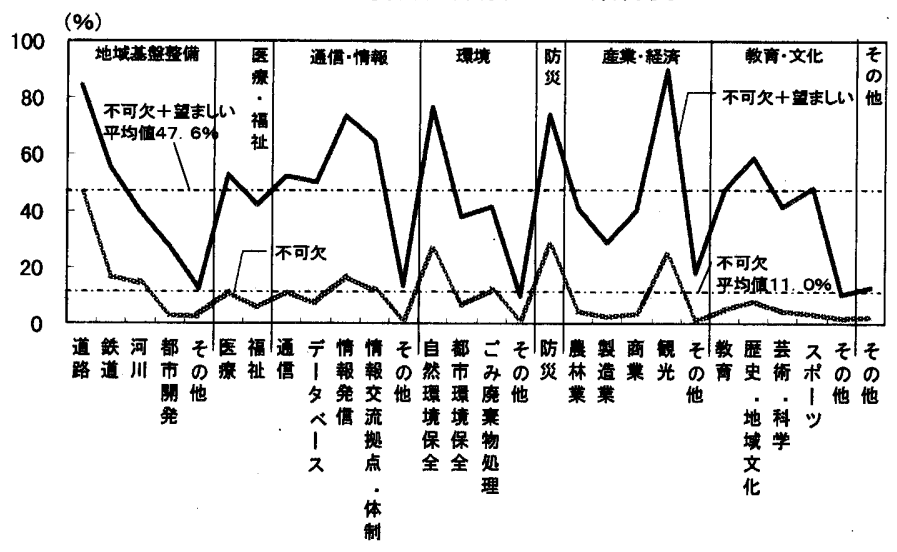

図 4 分野別の県境地域連擭必要比率

\begin{tabular}{|c|c|c|}
\hline 連携タイプ & 定羲 & 概念図 \\
\hline 圈域外連㩲型 & 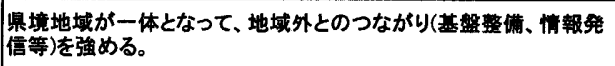 & \\
\hline 圈域内連簒型 & 紧境を越えて、地域相亘が連撘を強める。 & \\
\hline 補完型 & |㟟なった海源·環境を、祡境を越えて地域相互が活用する。 & (ton \\
\hline 重合型 & 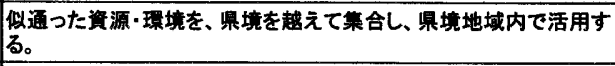 & (\$) \\
\hline 传存型 & 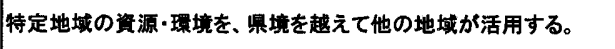 & $\Leftrightarrow$ \\
\hline 県内促進型 & 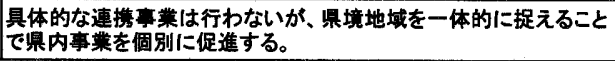 & 艮 \\
\hline
\end{tabular}

図 5 連携タイプの定義

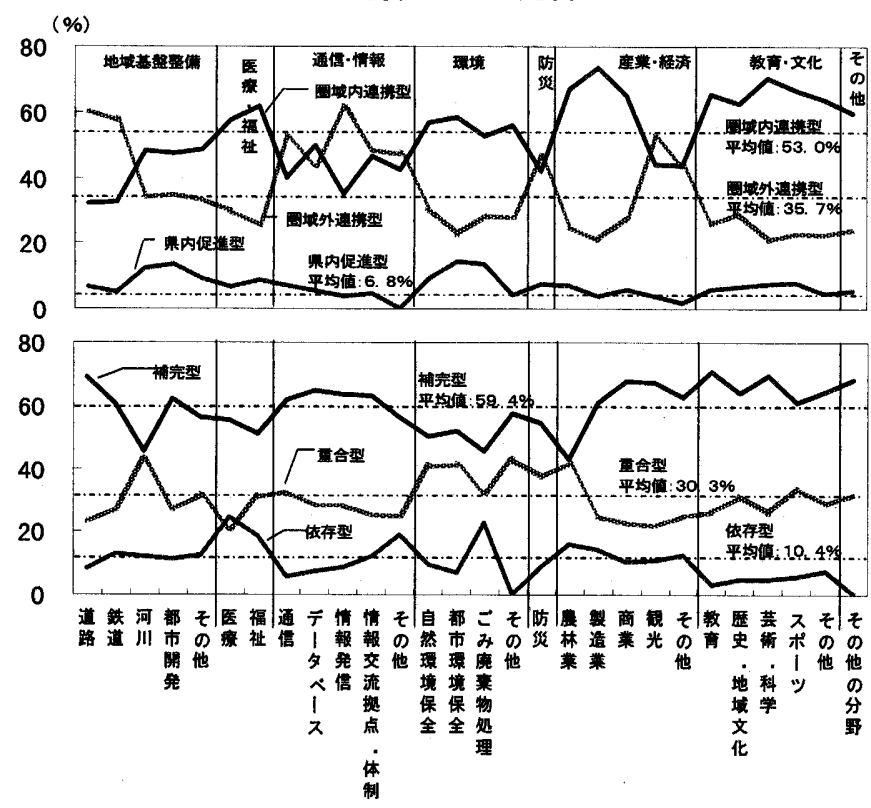

図 6 分野別にみた連掽タイプ別構成比率 
的共通性を求めていると考えられる。

\section{2) 連携タイプ別の特徴}

図 5 に示すように、連携事業の連携タイプを(1)県境地域が一体と なって県境地域外とのつながりを強める圈域外連携型、(2)県境を越 えて地域相互が連携を強める圈域内連携型、(3)具体的な連携事業は 行わないが、県境地域を一体的に捉えることで県内事業を個別に促 進する県内促進型、に分類して傾向をみる。自治体アンケートで図 5 の定義と概念図を提示し、分野ごとに期待する連携タイプの比率 を求めたものが図 6 である。全分野の平均では圈域内連携型が $53 \%$ と高く、圈域外連携型 $35.7 \%$ 、県内促進型 $6.8 \%$ 、不明 $4.5 \%$ となっ ている。圈域内連携型が過半数ではあるが、県境地域が一体となっ て圈域外と連携する圈域外連携型を $30 \%$ 以上が指向していること がみてとれる。

次に連携タイプ別に分野の傾向をみる。圏域内連携型の傾向が強 (泩4)ものは医療・福祉、環境、教育・文化カテゴリーの分野であ る。産業・経済カテゴリーは「農林業」、「製造業」、商業」が圈域 内連携型の傾向が強いが、「観光」は圈域外連携型がやや上回ってお り対外的集客も重視していることを示している。圈域外連携型の傾 向に着目すると、地域基盤整備では「道路」、「鉄道」、通信・情報で は「情報発信」があり、広域的な整備を目指している分野であるこ とが分かる。また県内促進型では環境カテゴリーの分野や地域基盤 整備の「河川」「都市開発」がやや高くなっている。

圈域外連携型の特徴を明確にするため、自治体アンケートの分野 別記入事例に着目する。地域基盤整備では「第 2 東名高速道路」、「九 州横断道」、「 J R 西日本と J R 東日本の接続」等の国土レベルの幹 線があげられる。また医療・福祉では「高度医療」や「離島対策」 等の圈域内では対応できない事業が指摘される。次に通信・情報で は「通信インフラ」、「ホームページの立ち上げ」、「フイルムコミッ ションからの情報発信」等の圈域にとらわれない情報システムがあ げられる。また環境では「瀬戸内海の環境維持」、防災では「大規模 地震」や「災害時相互協力」があり、これらは国土レベルの課題々 考えられる。一方、産業・経済では「自動車産業を中心とした地域 産業」、「世界遺産への集客」等、教育・文化では「研究開発施設の 有効活用」があげられ、全国有数の資源が特徵となっている。これ らから圈域外連携型は、国土レベルの基盤整備や圈域内で対応でき ない課題、広域的資源、圈域にとらわれない情報システムを特徴と した事業と考えられる。

最後に圈域内連携型を、a.異なった資源・環境を、県境を越えて 地域相互が活用する補完型、b.似通った資源・環境を、県境を越え て集合し県境地域内で活用する重合型、c.特定地域の資源・環境を、 県境を越えて他の地域が活用する依存型に区分して特徽をみる。全 分野平均では補完型 59.4\%、重合型 $30.3 \%$ 、依存型 $10.4 \%$ であり、 圈域内連携型は県境地域内での資源補完性が重視されていることが 分かる。いずれの分野でも補完型が多いが、環境や防災カテゴリー、 地域基盤整備の「河川、産業・経済の「農林業」では重合型と補完 型の差が縮小しており、自然資源に関連しやすい分野では同種の凟 源を集合化する傾向が読みとれる。

\section{3. 地域連搂計画事例の分析}

\section{3-1 計画の概要}

表 2 は事例分析として取り上げる 9 計画の概要である。まず、計 画書から(1)計画の目標と地域連携の方針（計画目標と連携方針）、(2) 実施方策（実施主体、事業費）の特徴をまとめる。

(1)「南とうほくSUNプラン（以下、S UNプラン)」: 仙台を中心 とする南東北中枢広域都市圈形成を目標としている。連携方針とし て、新産業育成など県境地域に 5 つのテーマ別の連携を提案してい る。実施方策については明記していない。

(2)「九州中央 77 地域活性化ビジョン（以下、九州中央）」：大分 · 熊本・宮崎県の広域都市ネットワーク（九州中央トライアングル） を目標としており、産業面など 3 テーマ別連携を連携方針としてい る。実施主体は事業ごとに想定しており、事業費は記載がない。 (3)「21 世紀F I T構想推進指針（以下、F I T)」: 東京圈との連携 を念頭においた福島・茨城・杤木県境地域の連携強化（F I T シン フォニー圈）が目標とされる。連携方針としては 4 テーマ別連携と 県境中央地域計画をあげている。実施方策は記載がない。

(4)「日本の心のふるさとゾーン整備構想（以下、心のふるさと）」: 特徵ある観光地域（日本の心のふるさと）形成を目標に、4 つのテ 一マ別回廊整備など観光ネットワークづくりを連携方針としている。 実施主体は事業全体に対応して想定され、個別事業主体や事業費は 記載がない。

(5)「富士箱根伊豆交流圈構想 (以下、富士箱根)」:日本屈指の広域 観光地域形成を目標としている。交流・発信など観光ネットワーク づくりを連携方針としている。実施主体は事業ごとに記載しており、 事業費は記載がない。

(6)「三遠南信地域交流ネットワーク推進整備計画（以下、三遠南 信)」:市民レベルの交流促進を目標としている。地域間や国内外と の交流、情報提供を柱とした交流ネットワークづくりを連携方針と している。連携組織を実施主体としており、事業費は記載がない。 (7)「俱利珈羅越えいにしえ街道整備計画（以下、俱利伽羅)」：歷史 国道整備事業として石川・富山県境に策定されている。連携方針を 事業整備として、ハード事業、ソフト事業に区分している。事業ご との実施主体、ハード事業の事業費が明記されている。

(8)「島根・山口県境地域共同アクションプログラム（以下、島根山 口)」：観光による定住交流の拡大を目標に、萩、津和野など県境を 越えた観光ネットワークづくりを連携方針としている。連携組織を 主な実施主体としており、事業費は記載がない。

(9)「やまなみミリオン回廊（以下、やまなみ）」：熊本・宮崎・鹿児 島県境における中小都市が連携した多様性を持つ地域づくりを目標 として、5つのテーマ別県境連携を連携方針とする計画である。実 施方策については記載されていない。

\section{$3-2$ 計画の分類と特街}

\section{1) 計画の分類}

9 計画に対して、2-2 で行った計画分類の適応を試みる。 (1)計画実施主体（地域計画・組織活動計画別）: 計画実施主体が明記 されているのは 6 計画である。その内「三遠南信」「島根山口」は 連携組織を主たる実施主体としており連携組織の連携活動計画と考 えられる。その他の計画は地城全体での実施を想定している。また 実施主体の記載がない「S UNプラン」、「F I T」、「やまなみ」の 3 計画については広範な分野を扱っており、連携組織のみの計画と は判断し難く、複数の活動主体を期待する地域計画と考えられる。 
(2)計画分野（総合分野・特定分野別）：計画目標と連携方針からみる と「SUNプラン」、「九州中央」、「F I T」、「やまなみ」は、テー マ別で複数の県境連携を提案して抢り総合分野の計画と考えられる。 「心のふるさと」、「富士箱根」、「島根山口」の 3 計画は観光に特化 している。また「三遠南信」は住民交流、「俱利伽羅」は道路整備に 特化した計画である。

(3)計画段階（ビジョン段階・事業整備段階別）：事業整備段階の特徴 として事業費に着目すると「俱利伽羅」のみ記載しており、事業整 備段階と考えられる。他の計画は、事業整備段階まで検討しておら ずビジョン段階と考えられる。

これらから、「S UNプラン」、「九州中央」、「F I T」、「やまな み」の 4 計画を総合ビジョン、「心のふるさと」、「富士箱根」を分野 ビジョン、「俱利伽羅」を分野整備、「三遠南信」、「島根山口」を連 携活動計画と分類する。

\section{2）計画分類ごとの特徴}

(1)計画策定の背景 : 計画はいずれも行政機関が事務局である連携組 織が立案している。これらの連携組織事務局にヒアリングした結果、 総合ビジョンは「S UNプラン」が旧国土庁等による「東北中部広 域都市圏整備計画調查」に対応して策定されている。同様に「九州 中央」、「F I T」、「やまなみ」の地域連携計画も事前に国の調查・ 計画がなされて抢り、これらの影響を受けていると言える。一方、 分野別ビジョンは「心のふるさと」、「富士箱根」ともに值接的な契 機となった事前の計画は認められず、地域内からの発案が計画化さ れたものと考えられる。また「俱利伽羅」は旧建設省の歴史国道整
備事業の実施計画となっている。連携活動計画は「三遠南信」の住 民交流促進、「島根山口」の観光活性化の様に計画に至る問題が明確 であったため、連携組織での実施が可能になったと考えられる。 (2)提案された事業数 : 各計画書から、最も細分化した単位で事業内 容が記述されている 421 事業を抽出した。事業数の計画平均は 46.8 である。計画分類別では総合ビジョン 51.8、分野ビジョン 65、分 野整備 41 、連携活動計画 21.5 となって招り連携活動計画が少ない。

「三遠南信」 34 事業、「島根山口」は 9 事業であり、連携組織で実 施するために限られた事業に集約される状況が推測される。

\section{$3-3$ 連携事業の特徵}

\section{1）連携タイプと連携分野の分類方法}

各計画から抽出した上記の提案事業について、連携タイプと連携 分野注5）を以下の様に分類した。分類方法は 3 名（40 代、30 代、 20 代の地域計画研究者）の合議注6)によった。

(1)連携タイプの分類：自治体アンケートで分類した圈域外連携型、 圈域内連携型、県内促進型の連携タイプ別の適応を判断した。判断 手順としては、圈域外連携型の判断 $\rightarrow$ 圈域内連携型の判断 $\rightarrow$ 県内促 進型とした。判断の基準として a . 圈域外連携型は圈域外との連携 （圏域外地名、圏域外への高速道路名等）が記述される場合と、自 治体アンケート記入事例を参考として、圈域性を問わない情報発信

(圈域内等が明記されないインターネット等)事業を採用した。b. 圈域内連携型は県境を越える連携（圈域内地名、県境を越える実施 組織等）が記述される事業とした。c．県内促進型は圈域外連携、 圈域内連携と判断されない事業とした。

\begin{tabular}{|c|c|c|c|c|c|c|c|c|c|c|c|c|c|c|}
\hline 地域 & 㩽䧃名 & 組溸名 & 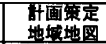 & 計面策定の背量 & 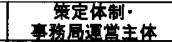 & 地城眯籍 & \multicolumn{2}{|c|}{ 計画目標と連携方針 } & & 菜数 & $\begin{array}{l}\text { 实旅 } \\
\text { 主体 }\end{array}$ & 重高 & 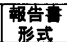 & 分面 \\
\hline \multirow{7}{*}{ 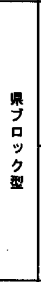 } & 站 & 蜓 & & 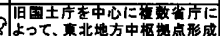 & 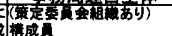 & 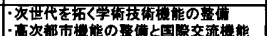 & 摗市周の形成 & 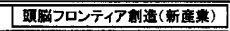 & \begin{tabular}{|l|l|}
6 \\
\end{tabular} & & & & & \\
\hline & 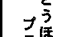 & 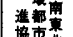 & & 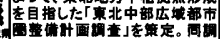 & & 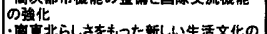 & & 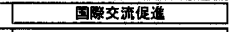 & 10 & & & 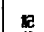 & $\begin{array}{l}A \\
4\end{array}$ & \\
\hline & 5 & 雷蓝 & & 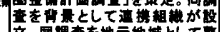 & 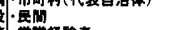 & 整值 & & \begin{tabular}{|c|} 
ハイクオリティイ生活女化舦造 \\
\end{tabular} & 12 & & II & 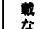 & 版 & \\
\hline & $\begin{array}{l}\text { S } \\
\text { N } \\
\text { N }\end{array}$ & 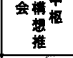 & & 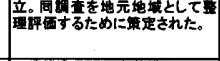 & 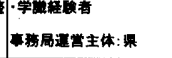 & 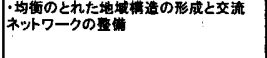 & 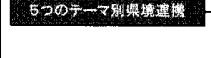 & 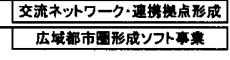 & \begin{tabular}{|l|}
14 \\
4 \\
\end{tabular} & $=\frac{\text { at }}{(46)}$ & $i$ & L & $\begin{array}{l}8 \\
6\end{array}$ & \\
\hline & 在地九 & 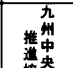 & & 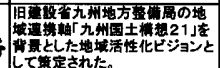 & 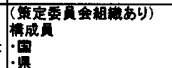 & 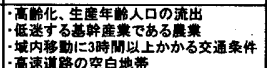 & 九州中央トライアングルの形成 & 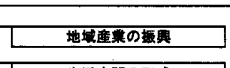 & 22 & & 濑事 & $e$ & $\begin{array}{l}\text { A } \\
4 \\
5\end{array}$ & \\
\hline & 寻海䖭 & & & & 材(代表自治体) & & & 生活空閳の形成 & 14 & & & $\frac{17}{2}$ & & \\
\hline & & 遗 & & & 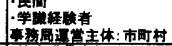 & & 520 & 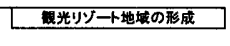 & 19 & ] & 别路 & & $\begin{array}{l}3 \\
3\end{array}$ & \\
\hline \multirow{10}{*}{ 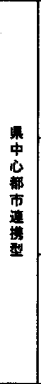 } & $\begin{array}{l}2 \\
1\end{array}$ & & & 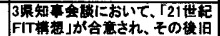 & 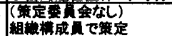 & 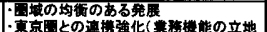 & 一周の形成 & 交流·物硫·伤籍 & 17 & & & & & \\
\hline & 蛪世 & & & 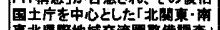 & -6 & 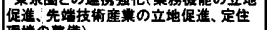 & & 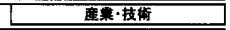 & 9 & & & & 4 & \\
\hline & 蕉整 & & & 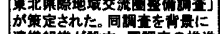 & & 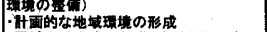 & & 学䒁·文化 & 12 & & & ition & & \\
\hline & 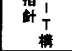 & & & 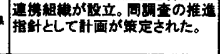 & 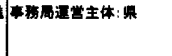 & 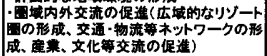 & 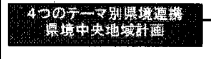 & 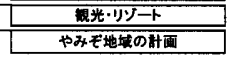 & \begin{tabular}{|l|}
9 \\
11 \\
\end{tabular} & (58) & $i$ & $i$ & $\begin{array}{l}5 \\
5\end{array}$ & \\
\hline & 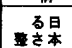 & 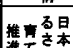 & & 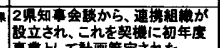 & 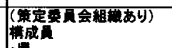 & 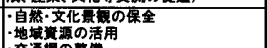 & 「日本の心のふるさをと壳形成 & 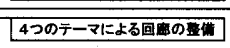 & 46 & & 想 & ta & $\begin{array}{l}A \\
4\end{array}$ & \\
\hline & 傮と昌 & 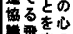 & & 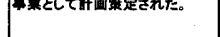 & 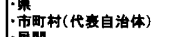 & & & ハードのネットトワークの鳌清 & 3 & & & 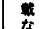 & 版 & \\
\hline & 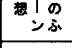 & 会 & & & 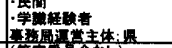 & & $2-35 \times 4$ & シフトのネットワークふくし & 23 & (72) & 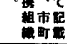 & $i$ & $\begin{array}{l}6 \\
6\end{array}$ & \\
\hline & 章至 & 肱山 & & 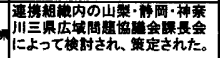 & 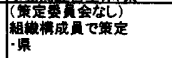 & 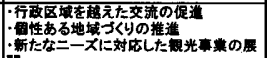 & 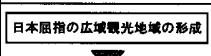 & 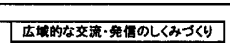 & 13 & & & te & $\begin{array}{l}\text { A } \\
4\end{array}$ & 悹 \\
\hline & 核 & 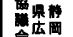 & & & & 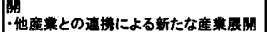 & & 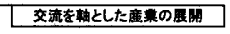 & 10 & & & 帮 & & \\
\hline & 亚 & 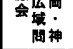 & & & 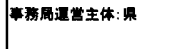 & 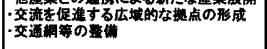 & $-3><4$ & 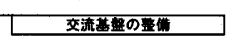 & 35 & (58) & & $i$ & $\begin{array}{l}2 \\
6\end{array}$ & \\
\hline 峦 & 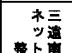 & *三 & & 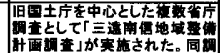 & 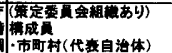 & 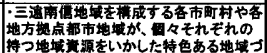 & 住民レベルの交䟽促進 & 地故四交流の推進 & 15 & & 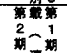 & & A & 七㫼 \\
\hline 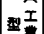 & 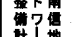 & & & 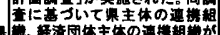 & & 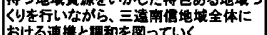 & & 国内外との交流の促進 & 8 & & & e & $\begin{array}{l}4 \\
\text { 师 }\end{array}$ & \\
\hline 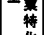 & 然地 & & & 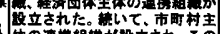 & 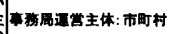 & & & 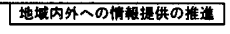 & 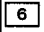 & & & な & P & \\
\hline 化 & 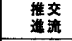 & & & 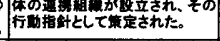 & & & & 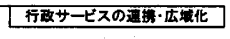 & 5 & & & & 9 & 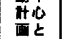 \\
\hline \multirow{5}{*}{ 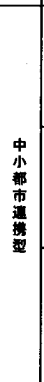 } & 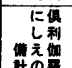 & & & 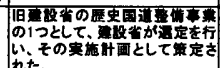 & 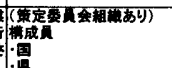 & 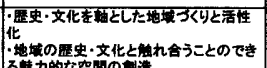 & 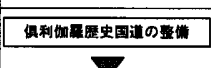 & 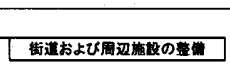 & 34 & & 到- & & $\begin{array}{l}\text { A } \\
4 \\
5\end{array}$ & 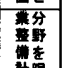 \\
\hline & & & & & 策眐禁 & 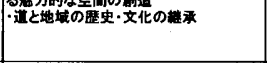 & & 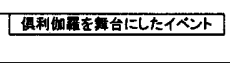 & & ]$_{(41)}^{\text {t }}$ & & tis & $\begin{array}{l}P \\
2 \\
4\end{array}$ & 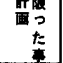 \\
\hline & 奇早地 & 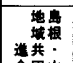 & & 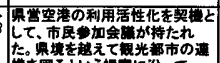 & 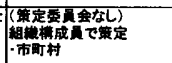 & 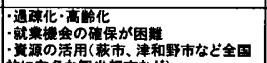 & 既光による定生交流の桩大 & 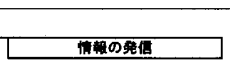 & \begin{tabular}{|c|}
6 \\
\end{tabular} & & 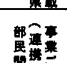 & ie & $\begin{array}{l}A \\
4\end{array}$ & 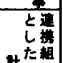 \\
\hline & 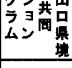 & 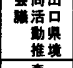 & & 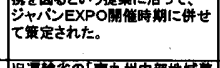 & 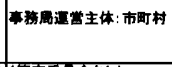 & & 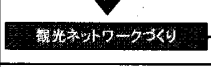 & 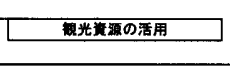 & & ] & 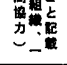 & 变 & $\begin{array}{l}p_{0} \\
7 \\
7\end{array}$ & 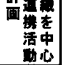 \\
\hline & $\sum_{i}$ & 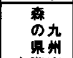 & & 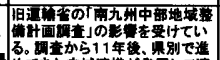 & 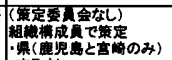 & 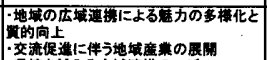 & 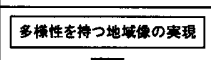 & 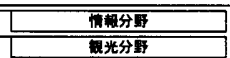 & \begin{tabular}{|l|}
10 \\
14 \\
\end{tabular} & & & & $\begin{array}{l}A \\
4\end{array}$ & 敕 \\
\hline
\end{tabular}


(2)連携分野の分類 : 分野は自治体アンケートで用いた 6 カテゴリー 28 分野を適応した。分類に際しては連携事業の目的で分類し、例え ば「観光のための情報発信」は目的である観光とした。

以上の結果、判定不能の 4 事業を除いた 417 事業の分類を行った。 以下の分析は 417 事業を対象としている。

\section{2）連擭事業のタイプ別特徽}

連携タイプ別の分類結果は、圈域外連携型 76 (18.2\%)、圈域内 連携型 197 (47.2\%)、県内促進型 144 (34.5\%) であった。

次に図 7 から計画分類別の特徵をみる。総合ビジョンは圈域内連 携型が $59.9 \%$ と多く、その他は圈域外連携型（22.2\%）と県内促進 型（17.9\%）に分散している。計画別では「S UNプラン」で圈域 外連携型が $37 \%$ であるのに対して「やまなみ」では $12.5 \%$ と低く、 地域規模が縮小寸ることによって圈域外連携の比率が下がるものと 思える。次に分野ビジョンは県内促進型が $64.1 \%$ と多い。これは地 域資源を活用しやすい観光分野の特性に起因しているものと考えら れる。また分野整備では圈域外連携型は提案されておらず、県内促 進型が多い。これは歴史国道整備事業が県境地域内の地域整備を目 的としているためと考えられる。最後に連携活動計画は圈域内連携 型 $(65.1 \%)$ と圈域外連携型（34.9\%）であり、県内促進型は提案 されていない。これらから連携組織の活動として県境を越える連携 事業に集中している傾向が読みとれる。

上記の特徵をまとめると、総合ビジョンは圈域内連携強化、観光 に特化した分野ビジョンは県内事業活性化、分野整備は事業志向、 連携活動計画は県外連携事業集中の傾向がある。

\section{3）連搭事業の分野別特街}

次に、図 8 から連携事業の分野別タイプ別構成からみた特徴を計 画分類ごとに示す。

(1)総合ビジョン:連携の分野は計画平均 13.8 であり他の計画分類に 比べて多くの分野を対象としている。ただし「九州中央」が 18 分 野であるのに対して「やまなみ」は 8 分野と地域規模での差異が認 められる。事業提案されている分野数では、産業・経済、通信・情 報のカテゴリーが全体平均を上回っていることが特徴的である。こ のうちすべての計画が事業提案を行っている分野としては「製造業」

「観光」、「データーベース」があげられる。「S UNプラン」、「九州 中央」「F I T」では国土構造上での拠点性を形成するために産業 集積強化を指向しているものと思える。また小規模地域である「や まなみ」においても多様な都市連携を形成するためにデーターベー ス構築を目指していることがみてとれる。これら特徴的分野の連携 事業内容を示す。まず産業・経済では「S UNプラン」の「製造業」 が圏域内連携型として「研究開発拠点ネットワーク事業」等 8 事業、 圈域外連携型として「技術の世界的アピールを狙った東北テクノ・ メッセ」等 2 事業を提案している。また「F I T」の「観光」では 圈域内連携型として「海洋系観光コースの設定」等 7 事業、圈域外 連携型として「共同観光キャンペーン」等 3 事業、県内促進型では 個別観光地振興を 5 事業あげている。一方通信・情報の事例として 「やまなみ」の「データーベース」では圈域内連携型の「地域情報 データー形式共通化と継続的更新」等 3 事業、圈域外連携型として 「共同ホームページの作成」等 2 事業があげられる。

これらから総合ビジョンは、圏域内連携事業を中心に産業・経済 による県境地域の経済振興、通信・情報による地域一体化を重視す
る傾向が読みとれる。

(2)分野別ビジョン: 観光を中心としているが、連携分野は平均 10 分野に及んでいる。カテゴリー別では地域基盤整備と教育・文化が 全体平均を上回っている。2 計画が共通する分野では、計画の目的 である「観光」の事業提案が多く、その他の分野では「道路」、「情 報交流拠点・体制」、「歴史・地域文化小、「芸術・科学」があげられ る。「心のふるさと」では、地域特性のある観光形成のために「歴史・ 地域文化」の提案が特徴的である。また「富士箱根」では日本屈指 の観光地形成のために「道路」の整備が特徴と言える。以下に提案 事業の内容を示す。まず「観光」分野で「心のふるさと」をみると 42 連携事業のうち県内促進型として「温泉開発」等観光地振興 22 事業があげられ、県内事業の促進が多いことがわかる。次に圈域内 連携型事業としては「味の学校開催」等 17 事業、圏域外連携型と しては「飛越ガイドブック」等 3 事業を提案している。また「心の ふるさと」の「歴史・地域文化」では、県内促進型として「歴史と ふれあいの里」等 7 事業、圈域内連携事業として「飛越民話伝説巡 回講演」等 4 事業、圏域外連携型として「全国・世界の職人が交流 する工芸職人フォーラム」等 3 事業あげられる。一方「富士箱根」 の「道路」では、県内促進型として「山梨ロマン街道整備」等 6 事 業が多いが、圈域内連携型として「県境を越える道路の改善」、圈域 外連携型で「第 2 東名自動車道等高規格道路整備」が提案され、全 国的観光地としての広域連携を目指していることがみてとれる。

これらから分野別ビジョンでは、目標である「観光」振興と観光 を支援する地域基盤整備の促進、観光のソフトとなる教育・文化を 県内促進型事業中心に進める傾向が読みとれる。

(3)分野整備 : 歷史国道事業の適応であるために、カテゴリー別では 地域基盤整備の「道路」事業が多い。次いで教育・文化の「歴史・ 地域文化」の事業が多い。また環境カテゴリーの「自然環境保全小、 「都市環境保全」についても提案されている。これらの事業内容と して「道路」では、圈域内連携型の「峠の交流拠点」等 5 事業、県 内促進型として「生活道路整備」等 13 事業をあげている。また、「歴 史・地城文化」では、圈域内連携型の「歴史国道案内標識」等 4 事 業、県内促進型として「宿場町の再現」等 6 事業をあげている。一 方、「都市環境保全」では県内促進型として「街道沿いいこいの広場」 等 3 事業がある。

この様に分野整備計画は、歴史国道を事業レベルで進めるための ハード事業とソフト事業が組み込まれている。

(4)連萼活動計画 :「三遠南信」では 12 分野が対象とされているのに 対して「島根山口」では 4 分野と差異がある。カテゴリー別では地 域基盤整備が少なく、通信・情報の分野数が全体平均を上回ってい る。この様に連携組織の活動として実施しやすい、ソフト事業を選 択している傾向がみてとれる。計画別では「三遠南信」が住民ネッ トワーク形成のために医療・福祉、教育・文化の両カテゴリーでの 提案分野が多い。また「島根山口」では、観光ネットワーク形成の ために観光の連携事業が多い。具体的事業として「三遠南信」の「福 祉」では圈域内連携型として「社会福祉協議会の交流会」等 2 事業 がある。また「島根山口」の「観光」では圈域外連携型として「が イドマップを他空港に設置」等 3 事業、圈域内連携型事業として「山 口きらら博開催に向けた花によるサイン計画」等 2 事業がある。

これらから連携活動計画が連携組織で対応可能な事業に対して、 


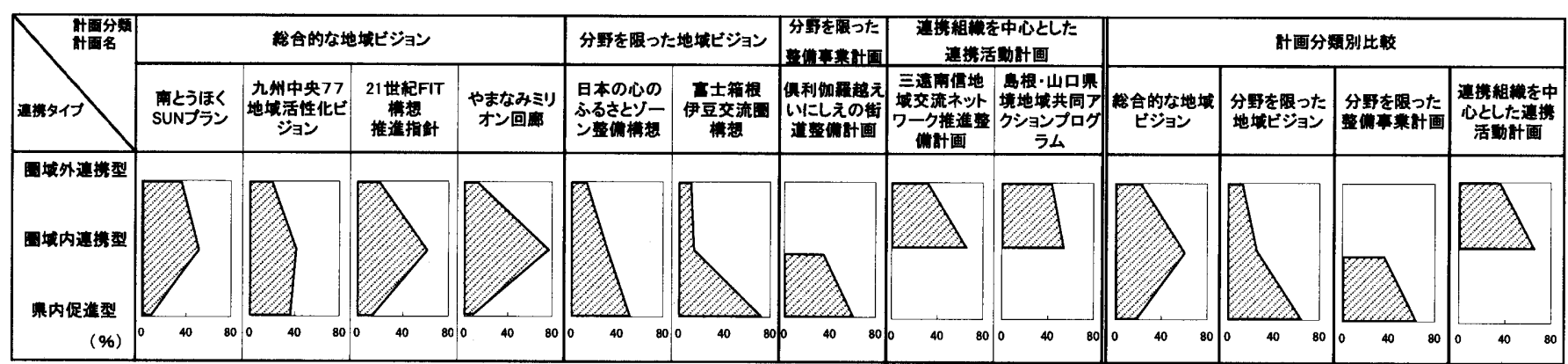

図 7 計画別・連㩲事業のタイプ別構成

\begin{tabular}{|c|c|c|c|c|c|c|c|c|c|c|c|c|c|c|c|}
\hline \multirow{2}{*}{ 分里 } & 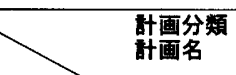 & \multicolumn{5}{|c|}{ 総合的な地域ビション } & \multicolumn{3}{|c|}{ 分里を限った地域ざション } & \multicolumn{2}{|c|}{ 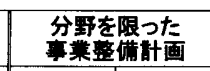 } & \multicolumn{3}{|c|}{ 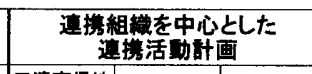 } & \multirow{2}{*}{ 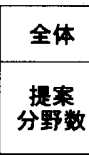 } \\
\hline & 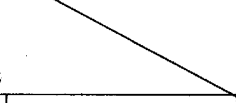 & 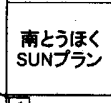 & 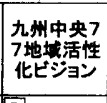 & 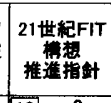 & 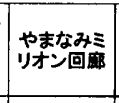 & 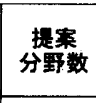 & 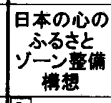 & 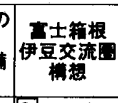 & $\begin{array}{l}\text { 提專 } \\
\text { 分野数 }\end{array}$ & 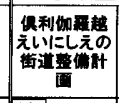 & $\begin{array}{l}\text { 提案 } \\
\text { 分野数 }\end{array}$ & 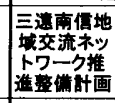 & 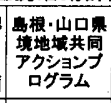 & $\begin{array}{l}\text { 提委 } \\
\text { 分数数 }\end{array}$ & \\
\hline \multirow{5}{*}{ 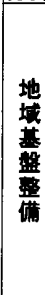 } & 道路 & 10 & ${ }_{2}^{3} \Omega_{1}$ & $10 \boldsymbol{1}_{7}^{3}$ & & \multirow{5}{*}{$\begin{array}{l}9 / 20 \\
(0.45)\end{array}$} & & ${ }_{6}^{8} \Delta_{1}^{1}$ & \multirow{5}{*}{$\begin{array}{l}6 / 10 \\
(0.60)\end{array}$} & \begin{tabular}{|l|}
18 \\
13
\end{tabular} & \multirow{5}{*}{$\begin{array}{l}2 / 5 \\
(0.40)\end{array}$} & & & \multirow{5}{*}{$\begin{array}{l}1 / 10 \\
(0.10)\end{array}$} & \multirow{5}{*}{$\begin{array}{l}18 / 45 \\
(0.40)\end{array}$} \\
\hline & 铁道 & 18 & ${ }^{1} 8.1$ & ${ }^{5} \boldsymbol{A}_{3}^{2}$ & & & & {$\left[\frac{5}{4} \Omega_{1}\right.$} & & $2 \pi$ & & & $10 \Omega$ & & \\
\hline & 河川 & & & & & & & & & & & & & & \\
\hline & 都市開発 & 1.8 & & & & & & $\frac{4}{4} \propto 8$ & & & & & & & \\
\hline & その他 & $5 \mathbf{A}_{2}^{3}$ & & ${ }_{1} \Omega_{3}$ & & & 108 & 118 & & & & & & & \\
\hline 䨪 & 医燐 & & & & & \multirow{2}{*}{$\begin{array}{l}1 / 8 \\
(0.25)\end{array}$} & & & \multirow{2}{*}{$\begin{array}{l}0 / 4 \\
(0.0)\end{array}$} & & \multirow{2}{*}{$\begin{array}{l}0 / 2 \\
(0.0)\end{array}$} & $1 \Omega_{1}$ & & \multirow{2}{*}{$\begin{array}{l}2 / 4 \\
(0.50)\end{array}$} & \multirow{2}{*}{$\begin{array}{l}3 / 18 \\
(0.17)\end{array}$} \\
\hline 变 & 椔社 & & 18.1 & & & & & & & & & $2 x_{0}{ }_{2}$ & & & \\
\hline \multirow{5}{*}{ 施 } & 通信(施祋、システム) & $2 \pi$ & & 18 & $\begin{array}{ll}3 & 8 \\
0\end{array}$ & \multirow{5}{*}{$\begin{array}{l}12 / 20 \\
(0.60)\end{array}$} & & & \multirow{5}{*}{$\begin{array}{l}3 / 10 \\
(0.30)\end{array}$} & & \multirow{5}{*}{$\begin{array}{c}1 / 5 \\
(0.20)\end{array}$} & & & \multirow{5}{*}{$\begin{array}{l}5 / 10 \\
(0.50)\end{array}$} & \multirow{5}{*}{$\begin{array}{l}21 / 45 \\
(0.47)\end{array}$} \\
\hline & 宁-タベース & $180^{1}$ & [2] $\Delta_{1}^{1}$ & 18. & ${ }_{0} \boldsymbol{\Delta}_{3}$ & & ${ }^{2} \boldsymbol{\Delta}_{1}^{\prime}$ & & & & & $17 \Omega_{0}^{1}$ & ${ }^{2} \boldsymbol{\Omega}^{1}$ & & \\
\hline & 标報祭借 & & ${ }^{4} \Delta_{2}^{2}$ & & & & & & & & & $4 \Omega_{0}^{1}$ & & & \\
\hline & 估辄交流挟点·休制 & ${ }_{0}^{5} x^{4}$ & ${ }_{3}^{5} \Delta_{1}^{\prime}$ & & ${ }_{1}^{6} \Delta_{4}^{\prime}$ & & $2 \boldsymbol{\Lambda}_{1}^{1}$ & 10 & & 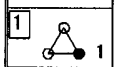 & & $40_{0}^{4}$ & 118 & & \\
\hline & その他 & $100_{0}^{1}$ & & & & & & & & & & & & & \\
\hline & 自然環填保全 & $2 \Omega_{2}$ & 18. & & & \multirow{4}{*}{$\begin{array}{l}6 / 16 \\
(0.375)\end{array}$} & & ${ }_{3}^{6} \AA_{3}$ & & 1.8 & & & & & \\
\hline 棵 & 都市摆境保全 & $\theta_{0} \Omega_{1}$ & 18 . & & & & & & & ${ }_{3}^{3} .8$ & & & & & \\
\hline 境 & こみ麿重物処理 & & 178 & & & & & & $(0.25)$ & & $\begin{array}{l}(0.50) \\
0\end{array}$ & & & $\begin{array}{l}(0.0) \\
(0.0)\end{array}$ & $\begin{array}{l}(0.28) \\
(0.76\end{array}$ \\
\hline & その地 & & $2 \Omega_{0}$ & & & & & 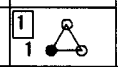 & & & & & & & \\
\hline 慗 & 防來 & & $1 \Omega$ & & & $\begin{array}{c}1 / 4 \\
(0.25) \\
\end{array}$ & & & $\begin{array}{l}0 / 2 \\
(0.0) \\
\end{array}$ & & $\begin{array}{l}0 / 1 \\
(0.0) \\
\end{array}$ & 10 & & $\begin{array}{r}1 / 2 \\
(0.50) \\
\end{array}$ & $\begin{array}{r}2 / 9 \\
(0.22) \\
\end{array}$ \\
\hline & 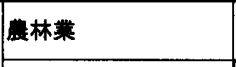 & & & ${ }^{4} \boldsymbol{S}_{3}^{1}$ & & & & $\frac{3}{3}, \Omega_{0}$ & & & & & & & \\
\hline 應 & 裂造菜 & ${ }^{10} \Delta_{8}^{2}$ & $\frac{2}{1}{ }_{1}$ & $8 \alpha_{5}^{3}$ & $3 \mathscr{R}_{3}$ & & & & & & & & & & \\
\hline 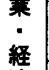 & 商烡 & & $D_{0}^{1}$ & & 1.8 & $\begin{array}{l}13 / 20 \\
(0.65)\end{array}$ & & & $\begin{array}{l}3 / 10 \\
(0.30)\end{array}$ & & $\begin{array}{l}1 / 5 \\
(0.20)\end{array}$ & & & $\begin{array}{l}2 / 10 \\
(0.20)\end{array}$ & $\begin{array}{l}19 / 45 \\
(0.42)\end{array}$ \\
\hline 筩 & 钼光 & $7 \AA_{6}$ & ${ }_{9}^{20} \boldsymbol{\Delta}_{7}^{4}$ & $\frac{15}{5} \Delta_{7}^{3}$ & $\frac{14}{2} \Delta_{11}^{1}$ & & 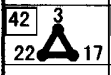 & $\frac{20}{14} \Delta^{4}$ & & $40_{4}$ & & $7 \Delta_{4}^{3}$ & $5 \boldsymbol{D}_{2}^{3}$ & & \\
\hline & その他 & & ${ }^{3} \Delta_{1}^{2}$ & & $5 \Omega_{4}^{\prime}$ & & & & & & & & & & \\
\hline & 教育 & & & $2 \sigma^{2} \cdot 2$ & & & 1.8 & & & & & 178 & & & \\
\hline 慗 & 歷史·地域文化 & $2 A_{1}^{1}$ & ${ }_{3}^{4} \triangle_{1}$ & $2 \Omega_{0}$ & & & $\frac{14}{7} \boldsymbol{\Delta}_{4}$ & ${ }_{6}^{6}, 8$ & & $\frac{10}{6} \Omega_{4}$ & & $8{ }^{8} \boldsymbol{A}_{7}^{1}$ & & & \\
\hline 商 & 芸吩·科学 & $17 \Omega_{1}$ & & $\frac{2}{2} \Omega_{1}$ & & $\begin{array}{l}9 / 20 \\
(0.45)\end{array}$ & $\frac{6}{6} .8$ & $\frac{2}{2} \Omega$ & $\begin{array}{l}5 / 10 \\
(0.50)\end{array}$ & & $\begin{array}{l}1 / 5 \\
(0.20)\end{array}$ & $2 \Omega_{0} 2_{2}$ & & $\begin{array}{l}4 / 10 \\
(0.40)\end{array}$ & $\begin{array}{l}19 / 45 \\
(0.42)\end{array}$ \\
\hline 炛 & スポーツ & & 10 & ${ }_{1}^{3} \Omega_{2}$ & & & & & & & & 28. & & & \\
\hline & その他 & $100_{0}^{1}$ & & & & & & & & & & & & & \\
\hline その甘 & & ${ }_{1}^{5} \Delta^{3}$ & $28_{0.2}$ & 18.1 & ${ }^{11} \boldsymbol{A}_{10}^{1}$ & $\begin{array}{l}4 / 4 \\
(1.0) \\
\end{array}$ & & 1.8 & $\begin{array}{r}1 / 2 \\
(0.5) \\
\end{array}$ & & $\begin{array}{l}0 / 1 \\
(0.0)\end{array}$ & $100^{1}$ & & $\begin{array}{r}1 / 2 \\
(0.5) \\
\end{array}$ & $\begin{array}{r}6 / 9 \\
(0.67) \\
\end{array}$ \\
\hline & 凡例 & & b: 圈域外 & & & 西 & 逨擭型 & & 。:罧内佂 & & & $\begin{array}{l}\text { 口左上の } \\
\text { 图の頂点 }\end{array}$ & 四解字 & 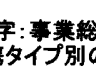 & 数事莱数 \\
\hline
\end{tabular}

因 8 計画別・連擭事業の分野別タイプ別構成 
圈域外連携事業、圈域内連携事業を進めている状況がみてとれる。

\section{4. 地域連䇽計画に対する自治体評価と課遺}

計画事例対象地域の自治体アンケート結果注7)により、地域連携 計画に対する自治体評価を計画分類別に分析する。なお分野整備は、 「俱利伽羅」に属する自治体数が 2 自治体と少ないため除外した。 図 9 は計画事例の認知と評価を示したものである。「計画推進に 参加」とする自治体が各計画分類共に $60 \%$ 近い。また「推進には参 加していないが計画内容を知っている」とするものを合わせると $70 \%$ 程度であり、自治体広域担当者には計画が比較的認知されてい ることが分かる。次に「計画推進に参加」、「推進には参加していな いが計画内容を知っている」とした回答者について計画の評価をみ る。まず「効果はない」は総合ビジョンが $20 \%$ 程度、連携活動計画 が 10\%程度であり、計画の効果が認められていると思える。一方、 分野ビジョンは 40\%以上が「分からない」としており、計画の効果 が自治体に明確でない状況を示している。

次に地域連携計画を策定する場合に期待する効果と、今回事例と した計画の評価を比較する。計画全体の傾向をみると、期待として 「策定事業の促進」、「県境を越える人・情報の熬がり」が求められ ていることが分かる。これに対して計画の評価では「県境を越える 人・情報の繁がり」が期待を上回っているが、「策定事業の促進」や 「自治体計画記載小、地域一体意識醸成」は期待を下回っている。 期待の高い項目からみると「策定事業の促進〕では連携活動計画、 総合ビジョンの評価が期待に比較的近く、分野ビジョンは期待に対 して評価を得ていない状況にある。次に「県境を越える人・情報の 䇣がり」では総合ビジョンの評価が期待に近く、分野ビジョン、連 携活動計画では期待を上回っている。また「地域一体意識酾成」で は総合ビジョンが期待に近く、分野別ビジョンは期待と評価の差異 が他と比較して大きい。「自治体計画記載」では、実施を評価してい るのは総合ビジョンのみとなっている。いずれの計画分類でも「県 境を越える人・情報の墼がり」はほぼ満足されており、計画推進段 階において自治体の期待と評価の乘離があることが読みとれる。

これらから計画分類別の課題を考察する。総合ビジョンは期待に 評価が比較的近く、期待との乘離がある「策定事業の促進」の方策 検討が重要と思える。次に分野別ビジョンでは、評価が「分からな い」とする自治体が多く、計画の内容を自治体の視点から明確にす ることが必要と思える。また連携活動計画では、自治体主体の連携 組織であることを勘案すると「自治体計画記載」が少なく、自治体 別計画への反映が重要と考えられる。

\section{5.まとめ}

本研究は県境地域における地域連携計画について、県境地域の自 治体アンケートと計画事例を分析したものであり以下の知見を得た。 1）県境地域の自治体は地域連携計画の必要性を感じており、計画 分類として、「総合的な地域ビジョン」、「分野を限った地域ビジョ ン」、「連携組織を中心とした連携活動計画」を求める傾向にある。

2）計画分類別に a.計画の背景、b.連携事業の連携タイプ、c.連携 事業の連携分野、d.計画評価で、以下の特徴が認められた。

(1)「総合的な地域ビジョン」は計画の背景に国の計画が関連してお り、県境地域内の連携事業を中心に、経済振興と通信・情報による

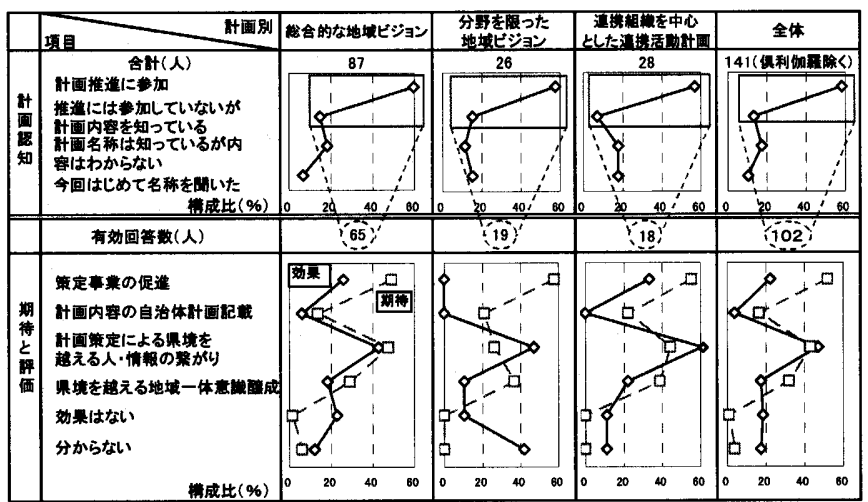

図9 計画事例の証知と評価

地域一体化を重視する傾向にある。計画評価が自治体期待に比較的 近く、「策定事業の促進」が課題である。

(2)観光に限定した「分野を限った地域ビジョン」は、地域内発案か ら発展しており、目標とする観光振興と関連事業を県内事業中心に 進める傾向がある。計画の効果が「分からないりとする自治体が多 く、計画内容を自治体の視点から明確にすることが課題である。

(3)「連携組織を中心とした連携活動計画」は、連携組織が対応可能 な課題に対して、県境地域内の連携事業、県境地域外との連携事業 を進める傾向にある。計画評価としては自治体計画への記載が少な く、自治体別計画との連携が課題である。

今後は、(1)県境地域を対象とした広域連合の活用などが進展する ことも想定され注 8)、広域行政制度適応時での地域連携計画のあり 方の検討、(2)計画で立案された連携事業が実施に至った事例から県 境地域における地域連携計画実施過程の検討、が必要と考えている。

\section{謝辞}

本研究を行うにあたり、(社) 東三河地域研究センターの楊迪鋼博 士から貴重な示唆を受けました。また調查分析には豊橋技術科学大 学建設工学系大貝研究室の長田剛和君に協力いただきました。ここ に記して謝意を表します。

注

注）県境を越える広域行政制度活用は、艮崎・佐賀県境地域の伊万里・北松 地域広域市町村圈組合、富山・岥阜県境地城の南砥広域連合など少ない。

2) 他の 11 例は、計画書を作成していないものが 4 例、事業列記のみで計画 書の要素を満たしていない場合が 4 例、立案時期が連携組織以前の調查・計 画を当該組織が活動方針としている場合が2 例、組織解散 1 例であった。

3) 7 地域類型の特徵を平均総人口と平均総面積で示すと、「県ブロック型 $\left(380\right.$ 万人、 1 万 $\left.\mathrm{k} \mathrm{m}^{2}\right)$ 」、「県中心都市連携型 $\left(112\right.$ 万人、 $\left.5 千 \mathrm{k} \mathrm{m}^{2}\right)$ 」「広域 (工業特化) 型 $\left(76\right.$ 万人、 2.5 千 $\left.\mathrm{k} \mathrm{m}^{2}\right)$ 」広域（商業・工業）型（42 万人、 2.5 千 $\left.\mathrm{k} \mathrm{m}^{2}\right)$ 小、都市型 $\left(273\right.$ 万人、8 百 $\left.\mathrm{k} \mathrm{m}^{2}\right)$ 」、「中小都市連携型（15 万人、

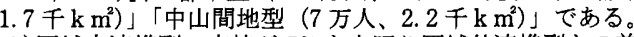

4 ) 圈域内連携型の支持が $50 \%$ 上回り圈域外連携型との差異が全分野平均を 上回っている分野に注目した。

5) 計画ごとに抽出した事業の規模は異なるが、連携事業の連携タイプと連 携分野という質的な分類は可能と判断した。

6) 計画書に記述される事業内容から 3 者での判定を行い、全員合意を基隻 とした。情報・通信などソフト面の事業は、計画間の判断に差異が出ないよ うに全計画の判断後に再検討を加えた。

7)計画地域ごとのアンケート回収率は、SUNプラン $54.4 \%$ 、九州中央 $43.8 \%$ F I T 57.1\%、やまなみ $66.7 \%$ 、心のふるさと $12.5 \%$ 、富士箱根 $56.6 \%$ 、俱利伽 羅 $50 \%$ 、三遠南信 $58.6 \%$ 、島根山口 $37.5 \%$ である

8）自治体アンケートに扔ける、今後の県境地域の望ましい行政形態につい ての設問では「広域連合制度等の自治制度 $(28.3 \%)$ 」が最も高く、2 位の現状

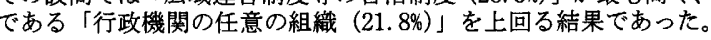

\section{孝文施}

1）戸田敏行、楊迪䤡、大貝彰：罢境地域における地域連携組織とその活動 実態の分析、日本建築学会計画系論文集 No.587 pp89 96 2005.1.

2) 嶋田喜昭、船渡悦夫、本多義明：地方圈に招ける県境を越えた地域連携 の方法に関する研究、土木計画学研究・論文集 No.14 pp313 320 1997.9 . 3）荒川俊介：都県境を超えた計画策定一「町田・相模原都市圈」構想の取 り組み一、都市計画 $226 \quad \mathrm{pp} 25 \sim 28 \quad 2000$.など 